Info Artikel:

Diterima: 08/05/2019

\title{
Efektivitas konseling kelompok kognitif behavioral untuk meningkatkan kesadaran akademik mahasiswa
}

\author{
Masnurrima Heriansyah \\ Universitas Mulawarman
}

\begin{abstract}
Academic quality improvement, self-development, and lecture completion can be realized if the students have academic awareness and are able to overcome various self-obstacles. This research aims to examine the effectiveness of cognitive-behavioral group counseling in increasing student academic awareness. The research type was the pre-experimental design of one group pre-test and post-test. The research sample was nine students under the guidance and counseling study program, Faculty of Teacher Training and Education, Mulawarman University. The analysis technique used was a descriptive analysis of percentages and the Wilcoxon test. The results showed that the student academic awareness increased based on the results of the pre-test and post-test as well as cognitive-behavioral group counseling was effective in increasing academic awareness after an effectiveness test was conducted.
\end{abstract}

Keywords: academic awareness, group counseling

This is an open access article distributed under the Creative Commons Attribution License, which permits unrestricted use,
distribution, and reproduction in any medium, provided the original work is properly cited. C 2019 by author.

\section{PENDAHULUAN}

Dalam meningkatkan kualitas pembelajaran di Perguruan Tinggi diperlukan kesadaran akademik dari mahasiswa dalam menjalankan proses perkuliahan. Menurut Hasibuan (2012) kesadaran adalah sikap seseorang yang secara sukarela menaati semua peraturan dan sadar akan tugas dan tanggungjawabnya. Kesadaran akademik merupakan wujud kesukarelaan mahasiswa dalam melaksanakan tugas dan tanggung jawab akademiknya sehingga memperoleh hasil yang optimal dalam menempuh pendidikan.

Hasil yang optimal dalam menempuh pendidikan dapat terlihat dari proses pembelajaran mahasiswa yang terimplementasi dalam penguasaan aspek-aspek pembelajaran yang meliputi aspek pengetahuan, aspek pemahaman, aspek sikap dan aspek perilaku. Reber (2010) mengungkapkan bahwa aspek pengetahuan adalah kumpulan informasi yang dimiliki seseorang atau kelompok atau budaya atau komponen mental yang di hasilkan dari semua proses apapun entah lahir dari bawaan atau di capai lewat pengalaman. Sedangkan aspek pemahaman menurut Sudaryono (2012) adalah kemampuan seseorang untuk menangkap makna dan arti dari bahan yang di pelajari yang dinyatakan dengan mengurai isi pokok dari suatu bacaaan atau mengubah data dari yang disajikan dalam bentuk tertentu kebentuk lainnya. Sabri (2010) mengungkapkan aspek sikap adalah suatu kecenderungan untuk mereaksi suatu hal, orang atau benda dengan suka, tidak suka atau acuh tak acuh. Menurut Arifin (2015) aspek perilaku adalah perbuatan atau tindakan dan perkataan seseorang yang sifatnya dapat diamati, di gambarkan dan dicatat oleh orang lain ataupun orang yang melakukannya. 
Berdasarkan observasi pada mahasiswa terdapat beberapa gejala yang muncul berkaitan dengan kesadaran akademik antara lain: (1) Penundaan dalam mengerjakan tugas yang diberikan oleh Dosen, (2) Minat membaca yang kurang, (3) Buku-buku mata kuliah akan di baca apabila di suruh atau ada tugas yang di berikan, (4) Tugas mata kuliah banyak di kerjakan dengan cara browsing internet atau mencontek karya orang lain, (5) Motivasi hadir dalam perkuliahan cukup rendah 6) Tidak siap dalam perkuliahan. Selain itu kesadaran akademik juga muncil akibat beberapa hal antara lain mahasiswa yang kuliah saat ini berbeda jurusan dengan yang di pilih mengakibatkan minat belajar berkurang.

Berdasarkan penyebaran skala kesadaran akademik yang dilakukan kepada mahasiswa Program Studi Bimbingan dan Konseling FKIP Universitas Mulawarman, menghasilkan bahwa 25\% mahasiswa tidak memiliki kesadaran akademik. Dalam menganalisis kesadaran akademik peneliti melakukan analisis terhadap empat aspek yaitu: (1) Aspek pengetahuan, (2) Aspek pemahaman, (3) Aspek sikap dan (4) Aspek perilaku. Penelitian ini juga diperkuat melalui penelitian Duval dan Silvia (2002) yang menunjukkan bahwa keberhasilan dan kegagalan seseorang dikelola oleh kesadaran diri dan kemampuan diri yang baik serta Zahrifah dan Darminto (2009) bahwa penggunaan strategi pengelolaan diri mampu meningkatkan disiplin belajar siswa. Dari beberapa fenomena dan data yang diperoleh memperlihatkan kesadaran akademik mahasiswa dalam kategori rendah oleh sebab itu diperlukan intervensi yang tepat dalam mengatasi masalah tersebut sehingga permasalahan dapat teratasi.

Dalam mengatasi permasalahan kesadaran akademik mahasiswa digunakan strategi layanan konseling kelompok kognitif behavioral. Penggunaan strategi ini atas pertimbangan kompleksitas fokus masalah serta jumlah mahasiswa yang mengalami rendah kesadaran akademik. Konseling kelompok kognitif behavioral adalah strategi konseling yang berfokus pada perilaku, kognitif, perasaan bermasalah dan semuanya terbentuk karena di pelajari dan oleh karenanya semua dapat diubah dengan proses belajar yang baru dan belajar kembali (Natawidjaja, 2009). Sedangkan menurut Corey (2012) konseling kelompok kognitif behavioral meliputi perilaku bermasalah, kognisi, dan emosi yang telah dipelajari dan dapat dimodifikasi oleh pembelajaran baru, anggota kelompok dilibatkan dalam proses belajar mengajar dan diajarkan cara mengembangkan perspektif baru tentang cara belajar.

Konseling kelompok kognitif behavioral sebagai sebuah strategi banyak digunakan dalam penanganan perilaku bermasalah seperti penelitian yang dilakukan oleh Amilin (2014) tentang penerapan konseling kelompok kognitif perilaku untuk menurunkan kecenderungan menarik diri (withdrawl) pada siswa kelas $\mathrm{X}$ MIA 4 SMA Negeri 1 Mantup Lamongan. Selain itu konseling kognitif behavioral juga digunakan dalam mereduksi prokrastinasi akademik hal ini berdasarkan penelitian yang dilakukan oleh Erfantinni, Purwanto dan Japar (2016) tentang konseling kelompok cognitive-behavior therapy dengan teknik cognitive restructuring untuk mereduksi prokrastinasi akademik. Penelitian yang dilakukan sebelum ini menunjukan bahwa konseling kelompok kognitif behavioral dapat digunakan sebagai proses intervensi.

Penelitian ini memiliki perbedaan dengan hasil penelitian yang sebelumnya yaitu dalam fokus permasalahan yang di atasi, penelitian ini berfokus pada peningkatan kesadaran akademik mahasiswa. Penerapan konseling kelompok kognitif behavioral akan memberikan kesempatan kepada mahasiswa yang memiliki masalah kesadaran akademik untuk merefleksikan diri dan menyadari permasalahannya serta dapat mengembangkan diri mereka kearah positif.

Pelaksanaan konseling kelompok kognitif behavioral melalui proses treatment sehingga dapat diketahui perubahan pada mahasiswa yang mengalami masalah kesadaran akademik. Sehingga penelitian ini diharapkan memberikan kontribusi peningkatan dan penguatan kualitas akademik mahasiswa dalam menjalankan perkuliahan sehingga mampu mengatasi berbagai masalah akademik dan memperoleh hasil yang baik dan positif. Oleh sebab itu penelitian ini menguji efektivitas konseling kelompok kognitif behavioral untuk meningkatkan kesadaran akademik mahasiswa.

\section{METODE}

Jenis penelitian ini adalah penelitian eksperimen, desain penelitian menggunakan pre experimental design one group pre-test and post-test. Langkah-langkah penelitian meliputi: (1) Pre-test yaitu mengetahui tingkat kesadaran akademik mahasiswa dengan menggunakan alat ukur skala kesadaran akademik, (2) Penerapan yaitu melakukan konseling kelompok kognitif behavioral melalui tahap initial stage, working stage: treatment plan and application of techniques dan final stage, (3) Post-test yaitu mengukur tingkat kesadaran akademik setelah diberikan perlakuan. Tempat penelitian dilaksanakan di Program Studi Bimbingan dan Konseling FKIP 
Universitas Mulawarman. Waktu pelaksanaan oktober 2018 sampai mei 2019. Sampel penelitian 9 mahasiswa. Pengambilan data menggunakan teknik purposive sampling.

Alat pengumpulan data adalah skala kesadaran akademik yang telah dikembangkan peneliti berdasarkan teori. Validitas yang digunakan dalam menyusun skala kesadaran akademik yaitu: (1) Validitas konstruk, dan (2) Validitas internal. Uji reliabilitas skala kesadaran akademik dilakukan dengan tujuan untuk mengetahui konsistensi derajat ketergantungan dan stabilitas dari alat ukur menggunakan Alpha Cronback. Analisis data menggunakan analisis deskriptif persentase dan uji wilcoxon.

\section{HASIL}

Proses penelitian dimulai melalui tahap awal dengan melakukan pengukuran tingkat kesadaran akademik mahasiswa. Pengukuran tingkat kesadaran akademik menggunakan skala kesadaran akademik meliputi aspek pengetahuan, aspek pemahaman, aspek sikap dan aspek perilaku.Hasil pengukuran awal menunjukan bahwa tingkat kesadaran akademik mahasiswa dalam kategori rendah. Data hasil pengukuran di jelaskan tabel 1 sebagai berikut:

Tabel 1. Tingkat Kesadaran Akademik Mahasiswa Sebelum Perlakuan

\begin{tabular}{|c|c|c|c|}
\hline \multicolumn{4}{|c|}{ Tingkat Kesadaran Akademik Mahasiswa Sebelum Perlakuan } \\
\hline Kriteria & Rentang Skor & Frekuensi & $\%$ \\
\hline Tinggi & $121-160$ & 0 & $\mathbf{0}$ \\
\hline Sedang & $81-120$ & 0 & $\mathbf{0}$ \\
\hline Rendah & $40-80$ & 9 & 100 \\
\hline \multicolumn{2}{|c|}{ Total } & 9 & 100 \\
\hline
\end{tabular}

Tabel 1 menunjukkan bahwa sebanyak 9 mahasiswa mengalami tingkat kesadaran akademik yang rendah. Hampir setiap mahasiswa memiliki kriteria yang rendah pada setiap aspek. Data analisis skala kesadaran akademik menjadi langkah awal dalam melaksanakan treatment.

Setelah hasil kesadaran akademik diketahui langkah selanjutnyanya adalah treatment konseling kelompok kognitif behavioral melalui tiga tahap yaitu (1) Initial stage, (2) Working stage: treatment plan and application of techniques, (3) Final stage. Proses treatment dilakukan dengan 12 kali pertemuan.

Setelah proses di laksanakan dilihat hasil perubahan yang terjadi setiap aspek kesadaran akademik untuk melihat perubahannya. Berikut ini data hasil sesudah diberikan perlakuan

Tabel 2. Tingkat Kesadaran Akademik Sesudah Mendapat Perlakuan

\begin{tabular}{|c|c|c|c|}
\hline \multicolumn{4}{|c|}{ Tingkat Kesadaran Akademik Sesudah Mendapat Perlakuan } \\
\hline Kriteria & Rentang Skor & Frekuensi & $\%$ \\
\hline Tinggi & $121-160$ & 9 & 100 \\
\hline Sedang & $81-120$ & 0 & $\mathbf{0}$ \\
\hline Rendah & $40-80$ & 0 & $\mathbf{0}$ \\
\hline \multicolumn{2}{|c|}{ Total } & Total & 100 \\
\hline
\end{tabular}

Tabel 2 memperlihatkan bahwa terjadi peningkatan dalam kesadaran akademik dari kriteria rendah meningkat ke kriteria tinggi pada 9 mahasiswa, hal ini disebabkan oleh faktor keinginan mereka untuk berubah kearah lebih baik, keseriusan dalam merencanakan rencana yang telah di buat oleh meraka, evaluasi terhadap hambatan-hambatan dalam melaksanakan perubahan.

Tabel 3. Efektifitas Konseling Kelompok Kognitif Behavioral Sebelum dan Sesudah Perlakuan

\begin{tabular}{cccc}
\hline No Resp & Total & Total & Keterangan \\
\cline { 2 - 3 } 1 & Sebelum Perlakuan & Sesudah Perlakuan & Efektif \\
\hline
\end{tabular}

Efektivitas konseling kelompok kognitif behavioral untuk meningkatkan kesadaran ... 


\begin{tabular}{llll}
\hline $\mathbf{2}$ & 60 & 130 & Efektif \\
$\mathbf{3}$ & 65 & 140 & Efektif \\
$\mathbf{4}$ & 70 & 148 & Efektif \\
$\mathbf{5}$ & 76 & 137 & Efektif \\
$\mathbf{6}$ & 63 & 134 & Efektif \\
$\mathbf{7}$ & 66 & 144 & Efektif \\
$\mathbf{8}$ & 64 & 139 & Efektif \\
$\mathbf{9}$ & 53 & 124 & Efektif \\
\hline
\end{tabular}

Tabel 3 menunjukan perbedaan ke arah peningkatan dalam kesadaran akademik setelah analisis hasil skala kesadaran akademik. Perbedaan antara sebelum dan sesudah juga dilakukan dengan analisis wilcoxon signed ranks test dengan hasil bahwa terdapat nilai signifikansi efektivitas penerapan konseling kelompok kognitif behavioral dengan $0,012<0,005$, sehingga hipotesis penelitian diterima.

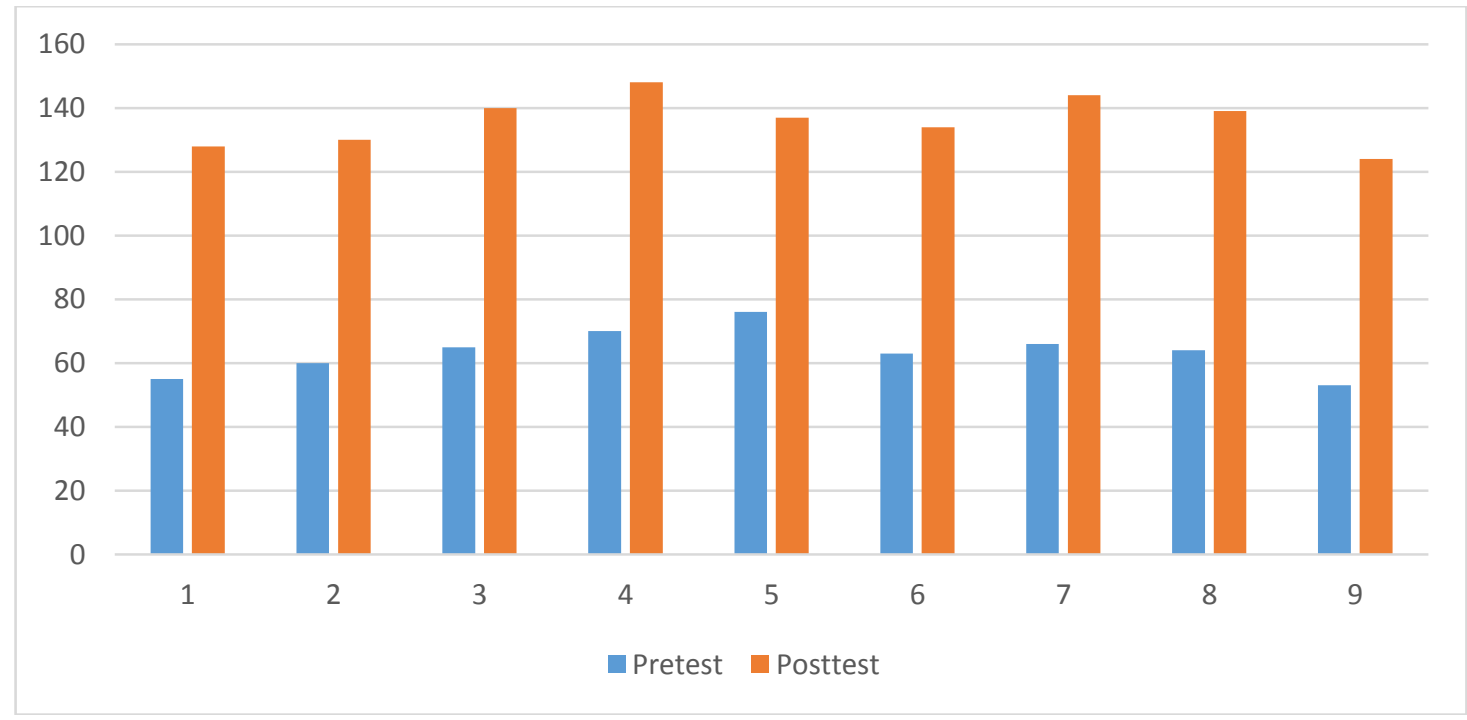

Grafik 1 Diagram Batang Hasil Pretest dan Posttest Kesadaran Akademik Mahasiswa

Grafik 1 menunjukan perbedaan dan terjadi peningkatan antara hasil pretest dan posttest dari 9 mahasiswa yang diberikan intervensi melalui konseling kelompok kognitif behavioral.

\section{PEMBAHASAN}

Penelitian ini dimulai dengan melakukan pengukuran tentang kesadaran akademik mahasiswa Program Studi Bimbingan dan Konseling FKIP Universitas Mulawarman. Pengukuran bertujuan untuk mengetahui bagaimana kondisi kesadaran akademik mahasiswa. Pengukuran yang dilakukan menggunakan alat ukur skala kesadaran akademik mahasiswa yang sudah di uji validitas dan reliabilitasnya. Menurut Azwar (2011) validitas adalah sejauh mana ketepatan dan kecermatan suatu instrumen pengukur (tes) dalam melakukan fungsi ukurnya. Sedangkan reliabilitas adalah sejauhmana hasil suatu proses pengukuran dapat dipercaya (Azwar, 2011). Setelah instrumen dinyatakan valid dan reliabel barulah digunakan untuk mengkur sehingga hasil diperoleh dapat dipercaya.

Dalam mengukur kesadaran akademik mahasiswa aspek yang di ukur meliputi aspek pengetahuan, aspek pemahaman, aspek sikap dan aspek perilaku. Pengukuran menunjukan bahwa 9 orang mahasiswa memiliki kesadaran akademik yang rendah dalam empat aspek yang dikembangkan. Berdasarkan hasil tersebut intervensi dapat dilakukan. Menurut Chaplin (2006) kesadaran adalah mengenai proses-proses mental sendiri atau mengenai eksistensi sebagai individu yang unik. Dengan membentuk kesadaran akademik seorang individu 
dapat bertanggung jawab terhadap dirinya. Menurut Purnamasari (2013) salah satu faktor yang menyebabkan mahasiswa melakukan kecurangan akademik adalah kurangnya rasa kesadaran dalam tanggung jawab.

Hasil pengukuran kesadaran kademik mahasiswa yang sudah di dapat menjadi dasar proses intervensi yang dilakukan melalui layanan konseling kelompok kognitif behavioral. Pelaksanaan penerapan konseling kelompok kognitif behavioral dilakukan melalui langkah-langkah: (1) Initial stage, (2) Working stage: treatment plan and application of techniques, (3) Final stage. Proses konseling kelompok kognitif behavioral dilakukan sebanyak 12 kali pertemuan. Pertemuan awal dimulai dengan memberikan gambaran data empiris mengenai kesadaran akademik, setelah itu melakukan kemitraan atau kerjasama mengatasi masalah yang mereka bawa ke kelompok. Anggota kelompok harus diberi tahu bahwa konseling kelompok kognitif behavioral merupakan bentuk penanganan masalah yang memiliki batas waktu dan tujuan mereka dapat dicapai dengan relatif cepat. Hal ini di karenakan konseling kelompok kognitif behavioral adalah pendekatan yang aktif, terstruktur, terarah, berfokus pada masalah, dan fokus saat ini untuk membantu mereka menangani masalah (Corey, 2012).

Selama fase awal kelompok, anggota belajar fungsi kelompok dari setiap sesi yang disusun dan disepakati. Tugas-tugas utama pada tahap ini berkaitan dengan membantu anggota berkenalan, mengarahkan anggota, meningkatkan motivasi anggota kelompok, memberikan rasa harapan bahwa perubahan itu mungkin terjadi, mengidentifikasi bidang-bidang masalah untuk eksplorasi, menciptakan rasa aman, dan membangun kohesi. Membangun kohesi adalah fondasi untuk kerja yang efektif selama setiap tahap perkembangan kelompok, dan pemimpin memiliki peran sentral dalam membangun kepercayaan dan menciptakan iklim kenyamanan (Corey, 2012).

Tahap kerja adalah tahap rencana perlakuan dan penerapan teknik. serta penilaian dan evaluasi. Pemimpin kelompok harus terus-menerus mengevaluasi tingkat keefektifan sesi dan seberapa baik tujuan perlakuan di capai. Tahap final pemimpin kelompok meminta anggota mentransfer perubahan yang telah mereka perlihatkan dalam kelompok ke lingkungan sehari-hari mereka berkaitan dengan kesadaran akademik. Anggota melatih apa yang ingin mereka katakan dan mempraktikkan dalam perkuliahan.

Umpan balik dari anggota dan orang lain sangat bermanfaat pada tahap akhir. Sesi dirancang secara sistematis sehingga perilaku baru secara bertahap dibawa ke dalam kehidupan sehari-hari. Layanan konseling kelompok behavioral di katakan afektif setelah dilakukan proses pengukuran dan terjadi perubahan dalam kesadaran akademik mahasiswa yang berikan perlakuan melalui pengukuran statistik. Selain itu keinginan dari subjek untuk merubah diri menjadi hal dominan dalam meningkatkan kesadaran akademik mahasiswa.

Penelitian ini dikuatkan oleh beberapa penelitian sebelumnya meliputi penelitian Habsy (2017) tentang model konseling kelompok cognitif behavior untuk meningkatkan self esteem siswa SMK dan Penelitian Fitriani dan Hidayah (2016) tentang keefektifan konseling kelompok adler untuk meningkatkan keterampilan interpersonal siswa SMP. Penelitian Nurcahyani dan Fauzan (2016) tentang efektivitas teknik relaksasi dalam konseling kelompok behavioral untuk menurunkan stres belajar siswa SMA. Penelitian Hariyanti (2014) tentang penerapan konseling kelompok rational emotive behavior untuk meningkatkan motivasi belajar siswa kelas viii G SMP Yayasan Pendidikan 17 Surabaya. Penelitan Muwakhidah dan Pravesti (2017) tentang keefektifan konseling kelompok cognitive behavior therapy untuk mengurangi keraguan pengambilan keputusan karier Siswa Sekolah Menengah Kejuruan. Penelitian Sanyata (2010) tentang teknik dan srategi konseling kelompok. Penelitian Dewi, Atmoko dan Triyono (2016) tentang keefektifan teknik self instruction dalam konseling cognitive behavior counseling untuk meningkatkan efikasi diri sosial Siswa SMKN 2 Malang. Penelitian Jabbar, dkk (2019) tentang konseling kelompok menggunakan pendekatan cognitive behavior therapy (cbt) untuk meningkatkan kematangan karir.

Perbedaan penelitian ini dan penelitian sebelumnya adalah pada konsteks fokus intervensi. Penelitian ini lebih menekankan pada kesadaran akademik. Hasil penelitian memberikan kekuatan bagi mahasiswa yang memiliki kesadaran akademik rendah untuk dapat memotivasi diri bahwa dengan memperkuat kesadaran akademik dapat memberikan peningkatan dalam prestasi akademik selama menyelesaikan perkuliahan di Perguruan Tinggi. 


\section{KESIMPULAN}

Berdasarkan hasil dan pembahasan dapat disimpulkan bahwa konseling kelompok kognitif behavioral efektif dalam meninkgkatkan kesadaran akademik mahasiswa dari hasil analisis wilcoxon signed ranks test dengan nilai signifikansi efektivitas $0,012<0,005$. Proses konseling kelompok kognitif behavioral dilakukan dengan tiga tahap yaitu (1) Initial stage, (2) Working stage: treatment plan and application of techniques, (3) Final stage. Sedangkan kesedaran akademik meliputi 1) Aspek pengetahuan, (2) Aspek pemahaman, (3) Aspek sikap dan (4) Aspek perilaku. Sebagai strategi intervensi konseling kelompok behavioral dapat dijadikan alternative dalam meningkatkan kesadaran akademik.

\section{REFERENSI}

Amilin, f. (2014). Penerapan Konseling Kelompok Kognitif Perilaku untuk Menurunkan Kecenderungan Menarik Diri (Withdrawl) pada Siswa Kelas X MIA 4 SMA Negeri 1 Mantup Lamongan. Jurnal BK Unesa, 5 (3), 456-465.

Arifin, B, S. (2015). Psikologi Sosial. Bandung: Pustaka Setia.

Azwar, S. 2011. Reliabilitas dan Validitas. Yogyakarta: Pustaka pelajar.

Chaplin, C.P. 2006. Kamus Psikologi. Jakarta: Rajawali Press.

Corey, G. (2012). Theory and Practice of Group Counseling, Eight Edition. US: BROOKS/COLE.

Dewi, F. A., Atmoko, A., \& Triyono, T. (2016). Keefektifan Teknik Self Instruction dalam Konseling Cognitive Behavior Counseling untuk Meningkatkan Efikasi Diri Sosial Siswa SMKN 2 Malang. Jurnal Kajian Bimbingan dan Konseling, 1(4), 172-178.

Duval, T. S., \& Silvia, P. (2002). Self-awareness, Probability of Improvement, and The Self-Serving Bias. Journal of Personality and Social Psychology, 82 (1), 49-61.

Erfantinni, I. H., Purwanto, E., \& Japar, M. (2016). Konseling Kelompok Cognitive-Behavior Therapy dengan Teknik Cognitive Restructuring untuk Mereduksi Prokrastinasi Akademik. Jurnal Bimbingan Konseling, 5(2), 119-125.

Fitriani, M., \& Hidayah, N. (2016). Keefektifan Konseling Kelompok Adler untuk Meningkatkan Keterampilan Interpersonal Siswa SMP. Jurnal Kajian Bimbingan dan Konseling, 1(1), 7-11. Retrieved from http://journal2.um.ac.id/index.php/jkbk/article/view/626.

Habsy, B. A. (2017). Model Konseling Kelompok Cognitive Behavior untuk Meningkatkan Self Esteem Siswa SMK. Perspektif Ilmu Pendidikan, 31(1), 21 - 35. https://doi.org/10.21009/PIP.311.4.

Hariyanti, d. E. S. I. (2014). Penerapan Konseling Kelompok Rational Emotive Behavior untuk Meningkatkan Motivasi Belajar Siswa Kelas VIII G SMP Yayasan Pendidikan 17 Surabaya. Jurnal bk unesa, 4(1).

Hasibuan, M. (2012). Manajemen Sumber Daya Manusia. Jakarta: PT Bumi Aksara.

Jabbar, A. A., Purwanto, D., Fitriyani, N., Marjo, H. K., \& Hanim, W. (2019). Konseling Kelompok Menggunakan Pendekatan Cognitive Behavior Therapy (CBT) untuk Meningkatkan Kematangan Karir. Jurnal Selaras: Kajian Bimbingan dan Konseling serta Psikologi Pendidikan, 2(1), 35-46.

Muwakhidah, M., \& Pravesti, C. A. (2017). Keefektifan Konseling Kelompok Cognitive Behavior Therapy untuk Mengurangi Keraguan Pengambilan Keputusan Karier Siswa Sekolah Menengah Kejuruan. Jurnal Kajian Bimbingan dan Konseling, 2(2), 66-75.

Natawidjaja, R. (2009). Konseling Kelompok, Konsep Dasar dan Pendekatan. Bandung: Rizqi.

Nurcahyani, I., \& Fauzan, L. (2016). Efektivitas Teknik Relaksasi Dalam Konseling Kelompok Behavioral untuk Menurunkan Stres Belajar Siswa SMA. Jurnal Kajian Bimbingan dan Konseling, 1(1), 1-6. Retrieved from http://journal2.um.ac.id/index.php/jkbk/article/view/625

Purnamasari, D. (2013). Faktor-faktor yang mempengaruhi kecurangan akademik pada mahasiswa. Educational Psychology Journal, 2(1).

Reber, S, A. (2010). Kamus Psikologi. Yogyakarta: Pustaka Pelajar.

Sabri, M, A. (2010). Psikologi Pendidikan Berdasarkan Kurikulum Nasional. Jakarta: Pedoman Ilmu Raya.

Sanyata, S. (2010). Teknik Dan Srategi Konseling Kelompok. Paradigma, 5(09).

Sudaryono. (2012). Dasar-dasar Evaluasi Pembelajaran. Yogyakarta: Graha Ilmu.

Zahrifah, F. L., \& Darminto, E. (2009). Penggunaan Strategi Pengelolaan Diri untuk Meningkatkan Disiplin Belajar Siswa. Psikologi Pendidikan dan Bimbingan, 12. 